\title{
Two Voices in Portraying Higgins in Pygmalion
}

\author{
Hongwei Chen \\ School of Foreign Studies, Beijing University of Science and Technology, Beijing, China \\ Email: rosechw@yahoo.com.cn
}

\begin{abstract}
Seen as a play in the stage of transition, Pygmalion marks Shaw's returning from his "discussion plays" to his earlier writings of the popular romance in his anti-romantic Shavian treatment. Portraying Higgins both as a man of great tradition who is distinguished for his intellectual superiority and a big child who can never free himself from maternal ties, Bernard Shaw makes the play a romance in a sense that differs from the normal expectation of the genre as its subtitle suggests.
\end{abstract}

Index Terms - power of speech, two voices, man of tradition, childish willfulness, romance

Seen as a turning point in George Bernard Shaw's life and work (Bloom, 1987), Pygmalion occupies a special position in Bernard Shaw's plays, marking a transition and change in style, and a turning from his former "discussion plays" to the writing of the popular romance mingled with his anti-romantic Shavian treatment. How to understand Higgins, the title character Pygmalion in the work, has always been the focus of critics' interpretations. Following a traditional approach, critics like Michael Holrayd try to illustrate the meanings of the play by alluding to the author's own biographical experience and his relationship with women, especially his mother and Mrs. Patrick Campbell, the actress whom he loved. John A. Bertolini, however, intends to connect Shaw's plays with the playwright's obsessed feeling towards the great tradition of literature he had inherited. According to Bertolini, "Higgins is a figure of himself [Shaw] as a playwright trying to master his own derivativeness specifically from Shakespeare" (Bertolini, 1991, p.101). The famous critic Harold Bloom lays special emphasis on the importance of myth in Pygmalion - not only the myth of Shaw's "Pygmalion and Galatea, but also that of Adam and Eve" (Bloom, p.20). Another different opinion can be found in Tracy C. Davis, who sees Higgins's teaching of Eliza in Pygmalion as a kind of colonizing attempt at home and their relationship as one of "master and slave, and colonizer and colonized" (Davis, 1998, p.225). Of course, there are also some feminist critics like J. Ellen Gainor who explore the meaning of the play by examining Shaw's mother/son relation and his paternal voice in his plays.

As readers, we may find that what Shaw employs in portraying Higgins is a kind of double-voices. He makes this professor of phonetics both a man of the great tradition who is distinguished for his intellectual superiority, and at the same time a big child who can never free himself from maternal ties with women. And as many critics have noticed, the play fails the genre of romance, which has been mentioned as its subtitle, because no traditional romantic love story takes place after all in the end of the play. Nevertheless, the playwright's two voices in portraying Higgins make the play end in romance in another sense, which might be even more charming than the traditional one of marriage or happy union.

In the preface to Pygmalion, Shaw states that "The reformer England needs today is an energetic phonetic enthusiast: that is why I have made such a one the hero of a popular play" (Shaw, 1992, p.151). So the role that Shaw essentially sets for Higgins is one of the elite of the society, a man of the great tradition of science, language and poetry. The opening scene of the play has made this point quite clear: under the portico of St. Paul's Church, all the characters are peering out gloomily at the rain, only one man has his back turned to the rest and is "wholly preoccupied with a notebook in which he is writing busily" (Shaw, 1992, p.159) ${ }^{1}$. This note taker is Higgins. The notebook in his hand not only makes him coolly detached from the scene of triviality around him, but also makes people immediately associate him with the "copper's nark," the reporter of criminals and the legal voice of society. And a few minutes later, he does prove this superiority of authority identified with him by his unusual knowledge of the origins of all the people there: "I can place any man within six miles. I can place him within two miles in London. Sometimes within two streets" (p.168). Therefore, the fundamental role that Higgins plays in Pygmalion is a possessor of knowledge: as he himself proudly declares, it is "phonetics. The science of speech. Thats my profession: also my hobby," and "I do genuine scientific work in phonetics, and a little as a poet on Miltonic lines" (pp.167-9). With the words of "science" and "poet" spoken, Higgins defines an exclusive world belonging to the male tradition originated from Shakespeare and Milton, the great masters of the human speech, which makes humans human and superior to animals.

It is this power of speech that serves as Higgins's standard to measure his relationship with the people around him. When the play begins, Higgins and Pickering are totally strangers. But with the revelation of their common interest in language, one as the student in Indian dialects and the other as the author of Higgins's Universal Alphabet, they immediately recognize each other as intimate friends belonging to the same "Empire." And Higgins's house in Whimpole Street also becomes Pickering's where they two can do their join research together. Later, we find a similar story happening between Higgins and Eliza's father. When Higgins sees Dollittle at first sight, his tone of talking to him

${ }^{1}$ Subsequent documentation of quotations from this play will be in-text notes with pages within parentheses. 
is the same rude and bullying one as to Eliza. But he soon discovers that "this chap has a certain natural gift of rhetoric," a potential oral power that can make him to "choose between a seat in the Cabinet and a popular pulpit in Wales"(p.193). This discovery at once wins from the arrogant professor a modest respect to the dustman-which is shown in the offer of the ten pounds and the quite flattering line said by him: "Pickering: if we listen to this man another minute, we shall have no convictions left"(p.194).

If the power of speech is the thing that enables Higgins to recognize a fellowship with the two male figures, it is also the thing that lets him trample Eliza to dirt from the start. A funny scene in Act $\mathrm{I}$ is that while Higgins and Pickering are busy acclaiming a warm friendship, the flower girl keeps on pitying herself aside by murmuring, "let him mind his own business and leave a poor girl"(p.168). The ironic contrast between the two gentlemen's self-absorbed talk and the girl's nursing of her injury forms a highly comic scene, but what is more important here is that it also shows vividly the fact of the men's total neglect of Eliza's existence and a suggestion of her unworthiness of any notice. Actually, for her failure in a proper speech, Higgins not only rejects her right to share the same roof with him —ordering her to "cease this detestable boohooing instantly; or seek the shelter of some other place of worship"(p.168) — but also suggests an absence of the power of reason and a sound human soul in her. So, Higgins feels perfectly justified in treating her roughly as an inferior creature: "That's all you get out of Eliza. Ah-ah-ow-oo! No use explaining. As a military man you ought to know that. Give her orders: that's what she wants"(p.183). He even tells her that "A woman who utters such depressing and disgusting sounds has no right to be anywhere-no right to live. Remember that you are a human being with a soul and the devein gift of articulate: that your native language is the language of Shakespeare and Milton and The Bible...."(p.168)

This self-consciousness as a privileged inheritor of the divine human knowledge makes Higgins feel instinctively identified with the great tradition of "Milton and The Bible," and naturally assume the roles of a God-like figure in front of Eliza: as a teacher, a paternal father, a commander, and above all a Maker. Appearing as a note taker in the opening scene, Higgins seems to be God taking down the "crime" of the poor girl, her blasphemy against "the divine gift of articulate speech" given by Him. Ever since then, Higgins has been trying to silence her, ordering her to "shut up" or "cease this detestable boohooing instantly". After he decides to bet with Pickering, "in six months-in three if she has a good ear and a quick tongue-I'll take her anywhere and pass her off as anything", that is, to be a creator to give her a new life, he begins to assume the right as a strict father: "If I decide to teach you, I'll be worse than two fathers to you " (p.177). Significantly here, Higgins sees this work of teaching Eliza as one similar to that in the Bible, and his fascination with the prospect of teaching her lies chiefly in the great pleasure as a Maker. Actually the very value of Eliza in his eyes lies in her lowness and her humblest position of "dirt" which is the very material for the creation: this is why he exclaims excitedly that "Shes so deliciously low-so horribly dirty"(p.177). Later, he tells his mother that the whole experience of teaching Eliza has filled his life, and that "you have no idea how frightfully interesting it is to take a human being and change her into a quite different human being by creating a new speech for her"(p.212).

Regarding himself as a teacher and creator, Higgins naturally takes the privilege of dominance over Eliza as granted. As J. Ellen Gainor once said, in Pygmalion, Shaw "associates power to command (politically or socially) with language" (Gainor, 1991, p.217). Higgins believes that by giving Eliza knowledge, he has given her part of the life that naturally and exclusively belongs to men. So when he discovers her leaving his house after the embassy ball, his response is not an anxiety about her safety, but resentment at her ungratefulness and the inconvenience it brings to his life. As he tells his mother later, he immediately gives Eliza's name to the police, setting them after her as if "she is a thief, or a lost umbrella, or something" (p.228). In fact, Eliza might indeed stand as a "thief" in his eye: departing without telling hime, she has taken away some valuable property of his, i.e., his originality: "You will jolly soon see whether she has an idea that I havnt put into her heads or a word that I havnt put into her mouth" (p.236). Firmly convinced that it is he who has "created this thing out of the squashed cabbage leaves of Covent Garden" (p.236), he thinks that she has neither the right to arrange her own fate, nor the right to encourage Fred's love to her. The very idea of marrying her to such a useless chap as Fred is totally unbearable to Higgins. He is annoyed with the possible marriage between them not because he is concerned with her happiness, but because "I'm not going to have my masterpiece thrown away on Freddy." So, if she marries, as a masterpiece by him, she shall marry the Lord of a British Empire, "the Governor-General of India or the Lord-Lieutenant of Ireland...or somebody who wants a deputyqueen"(p.247).

The interesting thing is that no matter how brilliant Eliza turns out to be and how dependent Higgins becomes on her in life, he never thinks of himself as a possible choice for the girl. The image that Shaw portrays of Higgins is a selfcentered and self-absorbed man who shows no interest in any other things but those that can be studied as a scientific subject. In dealing with women, Higgins never allows himself emotionally involved: he is, as Eliza says, a cruel tyrant, a man with no feeling. To her protest, his response is "The question is not whether I treat you rudely, but whether you ever heard me treat anyone else better" (p.242). To him, the beautiful landscape he sees outside his mother's house was no better than "a frozen desert "; in the same way, the best looking women in the world are to him but "blocks of wood." Throughout the play, he never regards Eliza as a human being worthy of any respect or special interest; instead, he calls her a baggage and guttersnipe, and threatens to throw her out, wrap her in brown paper, wallop her and put her in the dustbin, and once even lays a rough hand on her. He never bothers about her feelings or personality: to him, she is either useful or of "no use." Even when she turns out to be "a genius" in his scientific field, she is still but a parrot in his eyes. 
Finding that he can not live without her in the house, he is willing to invite her to join him and Pickering as "three old bachelors", to adopt her as his daughter, to settle some money on her, or arrange her to marry Pickering, but by no means would he marry her himself. In his world of male egoism no woman is allowed to intrude. The laboratory in the play seems to a reflection of Higgins's personality, in which woman is either an object of his scientific game or a housekeeper, but never a sharer of his real life like his male companion Pickering. So when his mother says that he has "spoiled that girl" in the end of the play, Higgins makes no protest, but "rattles his cash in his pocket; chuckles; and disports himself in a highly self-satisfied manner"(p.249)_because he knows perfectly well that he has never spoiled Eliza and that she is still the girl fetching his slippers while he, "jingling his money and his keys," will be forever the lord.

But in Pygmalion, while making Higgins a bullying voice of the male tradition, Shaw also portrays him as a big boy whose daily life depends wholly on the female figures, one who is careless and willful, and who stubbornly refuses to grow up. In Shaw's words, he is, "but for his years and size, rather like a very impetuous baby 'taking notice' eagerly and loudly, and requiring almost as much watching to keep him out of unintended mischief"(p.172). In the play, Higgins frequently swears and throws things around, just like a "boy" who can't behave himself and needs to be scolded now and then to be "nice". To Higgins and Pickering, the housekeeper Mrs Pearce is like a nurse and a mother. In Act II when Higgins leave his hat, overcoat and boots lying about in the living room and Pickering reminds him that Mrs Pearce might be annoyed the next morning, Higgins answers carelessly that she will "put them away all right. She will think we were drunk" (p.218). Actually, part of Eliza's attraction to him lies in that she is an extension of Mrs Higgins's role as a mother and Mrs Pearce's as a nurse: "shes useful," and she can find his things, remind him of his appointment and make his life pleasantly convenient.

Moreover, just as what Eliza calls him, a bully and a tyrant, Higgins impresses people with his childish willfulness. In Act II, Shaw writes, "to Higgins, the only distinction he makes between men and women is that when he is neither bullying nor exclaiming to the heavens against some featherweight cross, he coaxes women as a child coaxes its nurse when it wants to get anything out of her"(p.174). So, in the play, Higgins can intrude into his mother's at-home day, and imposes, in spite of her strong protest, his game of the "phonetic job" on her. And whenever he is scolded, he looks resentful and impatient and refuses to be "lessoned." In Act II, when Mrs Pearce urges him not swear, he denies at first the fact of "having ever uttered it," and then, when being cornered with evidence, he tries to escape into his male concept of superiority by saying that "Oh, that mere alliteration, Mrs Pearce, natural to a poet"(p.186). When finally the older lady goes further to urge him not to wipe his fingers on his dressing-gown, he loses all his patience to pretend to obey, and yells like an unreasonable child to her "Oh very well, very well: I'll wipe them in my hair in future"(p.187). Here we must admit that Higgins's willfulness partially comes from his mother's petting of him. In the play, Mrs Higgins is indeed quite a sensible woman, but she is never sensible enough to treat her middle-aged son as an adult. Although she seems to be fair to Eliza, she is still unhappy with the girl's refusal to buy the things as Higgins orders, so she says that "I'm afraid you've spoiled that girl, Henry. But never mind, dear: I'll buy you the tie and gloves"(p.249).

Nevertheless, Higgins's role as a child mainly results from his own choice, i.e., from his refusal to grow up in spite of his fascination with his male dominance in another respect. The fact is that audience may find two kinds of discourses used by Higgins in the play. For the most time, he speaks in the rhetoric identified with such masters as Shakespeare and Milton, and knows how to benefit himself and justify his irresponsible treatment of Eliza by using the concept and ideology in the tradition. But now and then, audience may notice that he would fall into the discourse of the child in talking. For example, in Act II, he tells Eliza that if she does not behave well, he will throw her out of the window, wallop her with a broomstick and put her in the dustbin. This style of speech betrays, of course, his paternal dominance over the girl, but the exaggerating tone in his speech also suggests the childish aspect in his character. In fact, to this big "boy," life is nothing but an interesting and absorbing experiment, a "game" that gives him great fun. In the scene of his seducing Eliza to stay in the room with a piece of chocolate and popping the half piece into her mouth in Act II, he is acting more like a boy treating a pet than an adult dealing with a fellow being. To Higgins, teaching the girl is a thrilling scientific work as well as an exciting game of betting. No matter how desperately Mrs Pearce and Mrs Higgins try to let him realize the destructive result the experiment might bring to the girl, he simply refuses to see anything in it. So it is no wonder that Mrs Higgins will call him "you silly boy," and him and Pickering "you two infinitely stupid male creatures"(p.212): picking up the girl like a pebble on the beach and throwing her out after the game, they two are indeed no better than a pair of senseless babies playing with a live doll.

But Higgins's resistance to grow up can best shown in his determination to be a bachelor. He enjoys playing the role as a male lord, but he does not like to take the responsibility as an adult. In Act II, when Mrs Pearce asks him what kind of dresses Eliza can use, Higgins becomes most impatient and then begins to complain to Pickering:

You know, Pickering, that woman has the most extraordinary ideas about me. Here I am, a shy, different sort of man. Ive never been able to feel really grown-up and tremendous, like other chaps. And yet shes firmly persuaded that I'm an arbitrary overbearing bossing kind of person (p.187).

Maybe this paragraph explains why Higgins can "never fall in love with anyone under forty-five" (p.201). As he declares that women upset everything, loving and marrying a young woman would mean, to him, an emotional demand which he can never spare- - I shall never get into the way of seriously liking young woman: some habits lie too deep to be changed" (p.201). His interest in Eliza lies only in her practical use to him, and he refuses to bother about any feeling 
in that "business." So when Mrs Pearce reminds him of his responsibility for that girl afterwards, he firmly cleans off his own hands in it: "when Ive done with her, we can throw her back into the gutter"(p.181). And later, when Eliza complains of his coldness and asks for "a little kindness" from him, he declares proudly that by no means will he change himself: "If you cant stand the coldness of my sort of life, and the strain of it, go back to the gutter"(p.246). He is a man who has known too well the sweetness of being a willful child to give it up: under the shelter of being universally "frank" to everyone and under the excuse of the glorious coldness of "Science and Literature and Classical Music and philosophy and Art," he has found a good way to enjoy the benefit of being a male without being responsible for it. So he is willing to offer Eliza a paternal protection and an economic support, but by no means will he sacrifice his male emotion, not to mention a marriage. In this respect, his determination to be a bachelor is not so much a refusal to enter the symbolic stage of maturity as a decline to compromise his male egoism. His obsession to be a big child is nothing but another form of patriarchal pride. He does turn out to be exactly what Eliza says about him: "youve no feeling heart in you: you don't care for nothing but yourself," and "you are a motor bus: all bounce up and go, and no consideration for anyone"(p.242).

From the analysis above, people can see that Higgins has been made a double character by Shaw: spiritually a dominant giant, but emotionally and psychologically a spoilt child. And it is these double voices that lead the play to an ambiguous ending in the sense of marriage. As a big child, he asks Eliza back to his house; but as an unyielding man, he refuses to compromise his male egoism. So, although the final decision of returning to Higgins or not seems lying in the hands of Eliza's choice, nevertheless, she has no real choices. On the one hand, Eliza condemns Higgins of being unkind to her and declares her independence by saying that she will rebel him by marrying Fred and become a creator herself by making something out of the young man. But on the other hand, Eliza's words demonstrate that she knows too well that she has no way to attach any extraordinary hope to be an intellectual equal to Higgins. Even when she declares that she will advertise and be a teacher herself, she is perfectly aware of the intruding nature of her action and her situation as "a child" who has "forgotten her own language" and lost her way in "his" country. As she tells Higgins:

I know I'm a common ignorant girl, and you a book-learned gentleman; but I'm not dirt under your feet. What I done (correcting herself) what I did was not for the dresses and the taxis: I did it because we were pleasant together and I com-came- to care for you... (p.246)

From this paragraph, we can see that although she insists on his respect for her, she is unconsciously playing the role of his pupil by frequently correcting her grammar mistakes. Higgins knows this well too: "Let her go. Let her find out how she can get on without us. She will relapse into the gutter in three weeks without me at her elbow" (p.238). Listening to their dialogue, audience may feel that her resentment against Higgins's coldness does not originate from a real rebellion, but a secret and hopeless desire of love that might even unknown to herself.

The sequel, arranging a marriage between Eliza and Fred, seems giving a final word to the whole unclear situation and Higgins's character who proves to be an unyielding man after all. But in fact, the double voices are still there, which eventually turn the play into a "romance" in another sense. In the sequel, readers find that Eliza does marry Fred after her "own" choice, but she does it only to find herself in an even more embarrassing state: now the couple has to make a living solely by relying on Pickering's financial aid and Higgins's intellectual support. And readers also find that Higgins assumes once again his former roles as a teacher as well as a big child. Just like in the former experience of teaching Eliza to speak, now he is found throwing himself into the task of teaching her to write with the same stormy intensity and concentrated patience. In return, he has the chance to be near to the "voice and appearance" he has grown accustomed to, because it "is astonishing how much Eliza still manages to meddle in the housekeeping at Wimpole Street in spite of the shop and her own family" (p.261).

Critics like J. L. Wisenthal point out Shaw's counterpoint use of the genre of romance because "the marriage between Higgins and Eliza, which the genre calls, has failed to occur" (Wisenthal, 1991, p.162). But in fact, in spite of the failure of a marriage between the two protagonists, the play still turns out to be a romance, not in the ordinary sense of marriage, but in the two emotional lives that Higgins's double characters arouse in Eliza. This mood has been subtly suggested in the end of the play, and is shown explicitly in the sequel. In the sequel, the unique relationship between Higgins and Eliza is finally made clear: in the everyday life of the "business," Higgins is still a spoiled child, who willfully "storms and bullies and derides"(p.262), and the man whom Eliza dislikes and stands up to ruthlessly; but, in the more private world of her imagination, he is the man whom she loves and whose "indifference" represents all the manly qualities she admires. As Shaw writes, while Eliza nags Higgins on the faintest provocation," at the same time, "She has a sense, too, that his indifference is deeper than the infatuation of commoner souls. She is immensely interested in him. She has even secret mischievous moments in which she wishes she could get him alone, on a desert island...." (p.262) Here Higgins's "indifference" that infatuates Eliza is the aspect that makes him a man of the paternal intelligence and the perpetual lord that she worships and loves in her fantasy world. It is in this respect that Pygmalion comes out eventually another romance.

\section{REFERENCES}

[1] Bloom, Harold. (1987). Introduction. In Harold Bloom (ed.), George Bernard Shaw. New York: Chelsea House Publishers.

[2] Bertolini, John A. (1991). The Playwrighting Self of Bernard Shaw. Carbondole: South Illionois University Press. 
[3] Davis, Tracy C. (1998). Shaw's Interstices of Empire: Decolonizing at home and abroad, In Christopher Innes (ed.), The Cambridge Companion to George Bernard Shaw. Cambridge: Cambridge University Press.

[4] Gainor, J. Ellen. (1991). Shaw's Daughters: Dramatic and Narrative Constructions of Gender. Ann Arbor: The University of Michigan Press.

[5] Shaw, George Bernard. (1992). Pygmalion and Major Barbara. New York, Bantam.

[6] Wisenthal, J. L. (1991). Having the Last Words: Plot and Countplot in Bernard Shaw. In Critical Essays on George Bernard Shaw. Macmillan: MacMillan Publishing Company.

Hongwei Chen was born in Henan, China, on $15^{\text {th }}$ July, 1966. She received her BA in English in Guangzhou Foreign Languages Institute (1987), MA and PhD in English and American literature in Beijing Foreign Studies University (1993, 2005), China, and her $2^{\text {nd }}$ MA in English literature in Leeds University (2004), England.

She has been working as a teacher in the English Department of Beijing Science and Technology University since 1993, teaching various literature and culture courses for the undergraduates and MA students. She had published in the past three years such academic works as Harold Pinter in the Post-War English Drama (monograph, Beijing: University of International Business and Economics Publisher, 2007), History of Contemporary English Drama (second author. Beijing: Beijing University Publisher, 2007), $20^{\text {th }}$ Century English Drama (Beijing: Beijing University Publisher, 2009). Her current research interests lie in the $20^{\text {th }}$ century English and American drama.

Dr. Chen is a professor of the School of Foreign Studies in USTB now. 